\title{
Retreatability analysis of the Musina copper mine tailings in South Africa: an exploratory study
}

\author{
N. K. Singo ${ }^{1}$ J. D. Kramers ${ }^{1}$
}

Received: 11 June 2020 / Accepted: 27 August 2020 / Published online: 16 September 2020

(c) The Author(s) 2020 OPEN

\begin{abstract}
In recent times, the potential beneficial uses of abandoned mine sites have been recognised and acted upon through the retreatment of tailings in order to win minerals of interest still available in economically viable concentrations. The most notable benefit (although not usually factored in financially) is that, once the tailings have been removed, the land has a greater potential to be developed further. The main aim of this study was to investigate the contents of copper and potentially harmful elements in the tailings of the Musina mine, an abandoned Cu mine in the northern Limpopo Province, in order to assess environmental hazards and to provide a first estimate of the feasibility of future economic rehabilitation. The concept of reclaiming was here seen in a broad way and ranged from the reworking of tailings or other residues to residential and/or recreational use. To quantify the potential economic importance and impacts of the metal content of the tailings, geochemical analysis of samples from auger holes and resource modelling were employed. Neutral to slightly basic $\mathrm{pH}$ values and very low concentrations of arsenic and lead showed that acid drainage and toxic groundwater contamination (apart from Cu itself) would not be a concern. Three-dimensional (3D) and two-dimensional (2D) models were applied to estimate the resource potential of the tailings dump. The models revealed that residual $\mathrm{Cu}$ in the Musina mine tailings is currently at 8555 tonnes. Accordingly, going forward, we recommend a formalised geometallurgical study to assess the economic feasibility of extracting $\mathrm{Cu}$, with a view to reworking the copper tailings dump. It is very important that this tailings dump be mined in future, in order to extract all $\mathrm{Cu}$ and ensure that the sterilised land (up to 95 ha) can be used for other purposes.
\end{abstract}

Keywords Tailings · Copper $\cdot$ Rehabilitation $\cdot$ Environmental impact $\cdot$ Heavy metals $\cdot$ Musina copper mine

\section{Introduction}

Mine closure is normally the last stage of production, especially when production costs overshoot mineral gains [17], the mine runs out of resources and/or commodity prices drop [36]. Today, mine closure is defined as a budgeted, orderly, safe and environmentally sound conversion of an operating mine to a closed state [26]. However, derelict and ownerless mines exist globally. These are mines whose owners or mining or lease holders have abandoned them without ensuring that environmental impacts are mitigated [12]. The most significant of these impacts relates to communities in the proximity, and the risks include cavities, sinkholes and open shafts, illegal mining, contamination of soils and ground water [30], and risks related to the minerals or chemical substances in the host rock, ore and residue deposits [27]. The increase in copper prices in the last decade [11] has led to the realisation of retreating of

Electronic supplementary material The online version of this article (https://doi.org/10.1007/s42452-020-03447-x) contains supplementary material, which is available to authorized users.

$\checkmark$ J. D. Kramers, jkramers@uj.ac.za; N. K. Singo, singo.kenneth@gmail.com | 'Department of Geology, University of Johannesburg, Johannesburg, South Africa. 
tailings. Amerigo Resources in Chile is processing tailings from EL Teniente Mine [39]; Woodlawn Mine in Australia managed by TriAusMin is retreating 10 million tonnes of tailings from 3 abandoned tailings dumps [38]. In most of these operations, extraction of copper $(>90 \%)$ was achieved by bioleaching, using microbial consortium, where elemental sulphur was added to the tailings and the $\mathrm{pH}$ of leach liquors allowed to fall to $\sim \mathrm{pH} 1$, at which point anaerobic conditions were imposed [6], Ahmadi et al. [2]. The results suggested that bio-processing these waste materials would have economic as well as environmental benefits [5].

In this context, we have studied the tailings of the Musina copper mine in Musina town (Fig. 1), northern Limpopo Province. It is understood that industrial-scale copper mining started here in 1914 and the mine was closed in 1992. No proper rehabilitation was carried out as part of its decommissioning process. The aims of this study are first to assess the environmental hazards associated with the tailings and second, to explore the economic potential of reclaiming $\mathrm{Cu}$. To achieve this, we have conducted systematic sampling by auger, geochemical analyses, mineralogy and resource modelling.

\section{Geological setting}

\subsection{Regional geology}

The Musina mine is situated in the central zone of the Limpopo mobile belt (Supplementary Fig. S1) which extends from Botswana to Mozambique, straddling the Limpopo-Zimbabwe boundary [3]. The highly deformed Limpopo belt (one of the oldest orogenic belts known) is more than $700 \mathrm{~km}$ long and $250 \mathrm{~km}$ wide and is situated between the Archean Zimbabwe craton in the north and the Kaapvaal craton in the south $[28,33]$.

The Limpopo metamorphic complex records two orogenic events, one at around $2.65 \mathrm{Ga}$ and another at $2.0 \mathrm{Ga}$ [25], both of which involved high-grade metamorphism. The complex consists of three zones: the Northern marginal, Central and Southern marginal zone. In the marginal

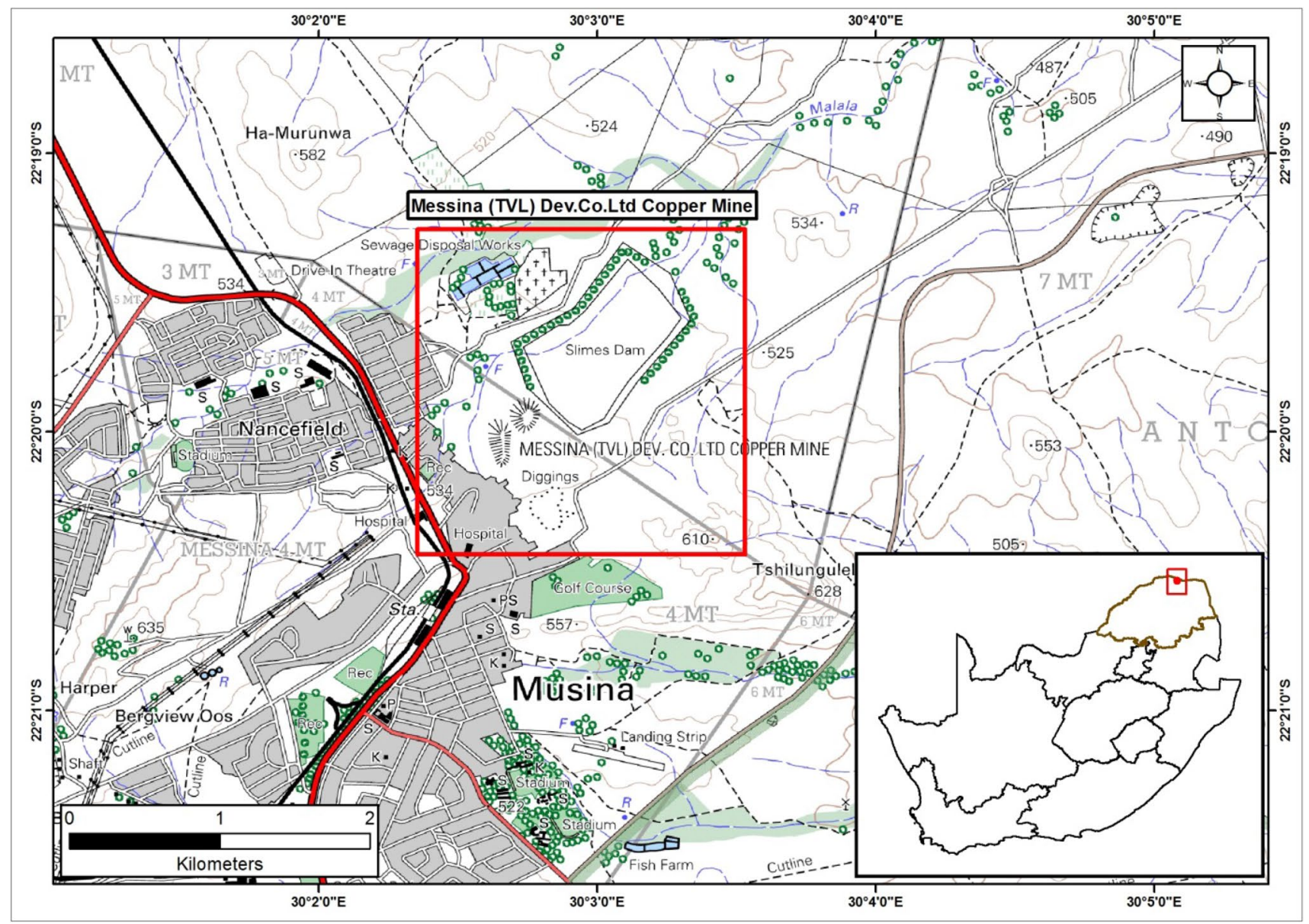

Fig. 1 Locality map of the study area at Musina, showing Musina town, its surrounding townships and the location of Musina copper mine (adapted: [31]) 
zones, structural trends are ENE-WSW, while the Central zone is characterised by $\mathrm{N}-\mathrm{S}$ trending structures [10]. Current isotope dating indicates that an important deformational event in the central zone, equated by many workers with the Limpopo orogeny, occurred at $2.0 \mathrm{Ga}[18,19,24]$. However, the large volume of crustally derived granitoids found in the Central Zone belongs to the older, $2.65 \mathrm{Ga}$ episode [25]. The $\sim$ Ga date reflects extensive strike-slip as well as thrust-sense shearing within the Limpopo belt when substantial relocation of the central zone occurred in a transgressive orogeny [19, 34].

\subsection{Local geology}

Five major copper deposits are known in the Musina area (Supplementary Fig. S2). All are aligned along the Musina Fault line, and they are situated where the line intersects the contact between metaquartzite (and other paragneisses) and granitic gneiss. The mineralisations appear to have been localised in fold structures, faults and fractures at the lithological contacts, due to competency contrasts. The Musina Fault transects all fabrics and structures associated with the $2.0 \mathrm{Ga}$ event, and thus, it (and the orebodies) must be younger than this, although no reliable age has been determined. The ore bodies appear hydrothermal and fall into four categories [3]: Breccia pipes, hydrothermal replacement bodies, open fissure mineralisation and transitions between the three above. The Musina and Harper mines differ from the other three in that the granitic host rock component is Singelele Gneiss, a homogeneous pink variety of the anatectic granitic gneisses in the area.

\section{Material and methods}

\subsection{Drilling and sampling materials}

Nominal $500 \mathrm{~m}$ by $500 \mathrm{~m}$ drill patterns were laid out over the Musina mine tailings dump, and a total of eight exploratory auger boreholes were drilled to a depth of $5 \mathrm{~m}$, from 31 October 2014 to 5 January 2015, using a traditional hand auger drill. Material from each successive metre was pooled into a sample, which resulted in a total of 40 samples from the tailings. Spillage from the tailings at four localities was also sampled as surface samples, yielding five samples (Supplementary Fig. S3).

\subsection{Sample analysis}

The main analytical work was done at the University of Johannesburg using inductively coupled plasma (ICP) optical emission spectrometry (OES) as part of a multi-element analysis on sample leaches. Cross-checks were carried out by X-ray fluorescence (XRF) on pressed powders by the Johannesburg laboratory of Sociéte Générale de Surveillance (SGS). Pre-treatment methods for the ICP-OES analyses were aligned to comply with the requirements for the International Organization for Standardization (ISO) 11464 of 1994.

\subsection{Aqua regia extractant determinations}

The aqua regia extraction procedure followed the ISO 11466 [22] specifications of 1995. Weighed aliquots (approximately $3.0 \mathrm{~g}$ ) of the tailings samples were placed in 200-ml Erlenmeyer flasks, after which $20 \mathrm{ml}$ of aqua regia was added. The flasks were sealed with parafilm and stored overnight at room temperature to allow for slow oxidation of organic matter in the tailings, followed by boiling under reflux for $2 \mathrm{~h}$ using a hot plate (Stuart CB300) set at a temperature of $125^{\circ} \mathrm{C}$.

The extract was allowed to cool and then passed through filter paper into a funnel, after which the flask was rinsed and the insoluble residue washed onto the filter paper. The filtered solution was evaporated and the remaining solid was moistened with about $5 \mathrm{ml}$ of water, to which was added, while mixing, $5 \mathrm{ml}$ of concentrated nitric acid, drop by drop where necessary, to reduce foaming. The mixture was then shaken vigorously to ensure total dissolution. The solutions were diluted to $100 \mathrm{~g}$ of 1 molar nitric acid in a plastic bottle and stored. For analysis of elements by ICP OES, $1 \mathrm{ml}$ of this stored solution was diluted further to $10 \mathrm{ml}$ of $4 \%$ nitric acid.

\subsection{Determination of tailings $\mathrm{pH}$}

As per ISO 10390 [20], representative samples weighing $10.0 \mathrm{~g}$ (weighed using a Precisa XB $620 \mathrm{M}$ Top Loading Balance) of the tailings (fraction $<2 \mathrm{~mm}$ ) were placed into $200-\mathrm{ml}$ Erlenmeyer flasks with $25 \mathrm{ml}$ volume of deionised water $\left(\mathrm{pH}-\mathrm{H}_{2} \mathrm{O}\right)$. This mixture was later shaken vigorously for $5 \mathrm{~min}$, by hand, followed by a waiting period of about $48 \mathrm{~h}$ at room temperature prior to determinations. An Erlenmeyer flask was sealed with parafilm and left overnight to allow for normal calibration. Because of the susceptibility of $\mathrm{pH}$-meter probes to particulate slurries, comprehensive and user-friendly $\mathrm{pH}$ (pH-Fix 0-14) colour indicator strips (also called dip in, read off) were used for the $\mathrm{pH}$ measurements. The test strips were dipped into the sample suspension until there were no longer changes in colour prior to taking readings. This ensured total calibration of the test kit. 


\subsection{X-ray diffraction and X-ray fluorescence}

XRD and XRF analyses were conducted at the Council for Geoscience to determine mineralogical and elemental composition, respectively. Tailings samples were dried, sieved ( $<200$ mesh) and ground in an agate mortar for XRD analysis. A representative sample of the tailings material was crushed and milled to a fine powder of around $20 \mu \mathrm{m}$ in grain size. A sub-sample was pressed into a shallow plastic sample holder against a rough filter paper to ensure random orientation.

XRD measurements were performed on a BRUKER D8 ADVANCE instrument with a 2.2-kW Cu long fine focus tube ( $\mathrm{Cu} \mathrm{Ka}, \lambda=1.54060)$ and 90 position sample changer. The system was equipped with a Lynx Eye detector with $3.7^{\circ}$ active area. Samples were scanned from 2 to $70^{\circ} 2 \theta$ at a speed of $0.02^{\circ} 2 \theta$ steps size/ $0.5 \mathrm{~s}$ and generator settings of $40 \mathrm{kV}$ and $40 \mathrm{~mA}$. Phase identification was based on BRUKER DIFFRAC Plus-EVA evaluation programme. Routinely, phase concentrations are determined as semi-quantitative estimates (with accuracy $\pm 5 \%$ ) using the reference intensity ratio (RIR) method and relative peak heights/areas proportions [4]. Mineral composition of the tailings samples was determined by the external standard method of Chung [7]. Pellets for XRF major elements analysis were prepared as follows: the milled sample $\left(<75 \mu \mathrm{m}\right.$ fraction) was roasted at $1000^{\circ} \mathrm{C}$ for at least $3 \mathrm{~h}$ to oxidise $\mathrm{Fe} 2+$ and sulphur and determine the loss on ignition (LOI). Glass discs were prepared by fusing $1 \mathrm{~g}$ roasted sample and $10 \mathrm{~g}$ flux consisting of $49.5 \% \mathrm{Li} 2 \mathrm{~B} 4 \mathrm{O} 7$, $49.5 \% \mathrm{LiBO} 2$ and $0.50 \%$ Lil at $1150^{\circ} \mathrm{C}$.

\subsection{Methods for 3-dimensional block modelling and resource estimation}

In order to enable data visualisation and evaluation of resources, a 3D block model was created for the area covered by the tailings dump. These models include all the data and interpret the tailings dump volume. A block model for the grade estimation was generated using the modelled surfaces for the topography of the tailings dump and filling the volume between the two surfaces. Vulcan ${ }^{\mathrm{TM}} 3 \mathrm{D}$ software version 9.1.7 was used to model dump solids and surfaces, followed by block model estimation. Inverse distance squared (IDW) and ordinary Kriging (OK) methods were trialed to obtain reserve estimates.

An Excel database file format containing drill hole and sampling information was imported into a database in
Vulcan using a database design file (dhd.dsf). The data validation process in Vulcan software forms part of quality assurance and quality control (QAQC) and is suitable for undertaking tailings dumps resource estimation. The accuracy and provenance of the data are of a satisfactory standard. Eight drill holes were used for the Musina mine. The dataset was validated for unique collar location and overlapping intervals. No major errors were identified on either dataset. The data included collar coordinates in the Universal Transverse Mercator (UTM), World Geodetic System (WGS84) system, downhole assays and downhole surveys.

\section{Results of analyses and discussion}

\section{1 $\mathrm{pH}$ and mineralogy of tailings}

$\mathrm{pH}$ values obtained from the entire study area showed a neutral to weakly basic reaction throughout (7.0-9). Variations in $\mathrm{pH}$ levels with depth were insignificant; all tailings were alkaline. This can probably be ascribed to the weathering of plagioclase feldspar, which is a constituent in the host rock of the mineralisation [3], and occurs at 6-8\% in the tailings, and to the low content or even absence of pyrite (not detected by our XRD analysis). The alkaline reaction of the tailings of the Musina mine means that no, or little, mobilisation of toxic and other metal ions is likely to take place. Instead, adsorption will dominate.

Due to erosion, tonnes of tailings material spill from the Musina mine tailings into the nearby river and surrounding environment every year in the rainy season. Spillage samples, like the tailings themselves, have neutral to slightly alkaline $\mathrm{pH}$ values (7.5-8). This river is an important water source for communities living downstream [32], and it is thus important to note that this $\mathrm{pH}$ value signals no high level of metal contamination risk.

Tailings samples analysed from the Musina mine (Table 1) comprise amphibole, quartz and clinochlore (a variety of chlorite) as the most abundant minerals. No dolomite, talc, ilmenite or serpentine was detected, but gypsum and smectite occurred as secondary minerals. The primary ore is chalcopyrite, with quartz and albite gangue [40]. The presence of plagioclase and abundant quartz in the tailings is in accord with this. Amphibole is known to occur in the Singelele gneiss, which forms most of the country rock of the mineralisation. Chlorite is the low-grade metamorphic or hydrothermal alteration product of most of the mafic minerals including probably biotite. When chloritisation occurs, alkali
Table 1 XRD analysis of two Musina mine tailings, mineral contents expressed in wt.\%

\begin{tabular}{llllllll}
\hline Sample & Gypsum & Amphibole & Plagioclase & Quartz & Clinochlore & Mica & Smectite \\
\hline KSM6C & 8 & 41 & 6 & 34 & 4 & 3 & 4 \\
KSM8B & - & 2 & 8 & 49 & 30 & tc & 10
\end{tabular}


minerals are usually released which means some neutralising capacity arises from that process. Although sulphides are seen in some rock samples, they were not detected in the $\mathrm{XRD}$ analysis and therefore are minor. Also, they are already oxidised as seen from the presence of malachite. Aluminosilicate minerals, such as plagioclase, can also neutralise acid upon weathering, although they are not as reactive as carbonate minerals [35]. In this process, $\mathrm{Na}$ and $\mathrm{Ca}$ are dissolved out of plagioclase while Al and Si produce clay minerals. Gypsum occurs as a secondary mineral, probably formed due to the alteration of plagioclase during the oxidation of sulphides in the tailings.

\subsection{Element concentrations and correlations}

Concentrations of the elements analysed for $(\mathrm{Al}, \mathrm{As}, \mathrm{Au}$, $\mathrm{Ca}, \mathrm{Co}, \mathrm{Cr}, \mathrm{Cu}, \mathrm{Fe}, \mathrm{Mg}, \mathrm{Mn}, \mathrm{Ni}, \mathrm{P}, \mathrm{Pb}$ and $\mathrm{Zn}$ ) are listed in supplementary Table $\mathrm{S} 1$. As and $\mathrm{Pb}$ are below detection limits ( 8.3 and 10 ppm, respectively) for all samples. Au was detected in 4 borehole samples and 1 from a spillage, at levels below $0.2 \mathrm{ppm}$. Cu concentrations range from 326 to $2741 \mathrm{ppm}$ with an average of $954 \mathrm{ppm}$. Other metals present in significant amounts are Al (6844-23,992 ppm), Ca (2986-14,299), Fe (17,767-60,114), Mg (5104-17,229), $\mathrm{Mn}$ (84-396) and P (238-616). Co, Cr and Ni are present in trace amounts generally below $100 \mathrm{ppm}$. The sum of concentrations of elements analysed ranges from 34,161 to $117,974 \mathrm{ppm}$, reflecting their content dissolved in the ISO 11466 [22] aqua regia procedure, that is, not hosted in silicates (except clay minerals and chlorite).

Correlation patterns in geochemical datasets are useful to establish associations between elements, for instance, to elucidate in which phases they occur $[8,23]$. We have explored this aspect using Microsoft Excel. The raw Musina mine tailings data show many significant correlations (correlation coefficient $r>0.5$, see Supplementary Table S2). These are, however, dominated by the variations in total content of extractable elements (those not hosted in insoluble silicate minerals) in the tailings and therefore not informative. This effect is eliminated by considering element amounts as percentages of the sum of element contents determined for each sample. These values are listed in supplementary Table S3. The correlation matrix (Table S4) shows few significant correlations (Fig. 2), which, however, can yield relevant information. Negative correlations (Fe vs. Ca, Mg vs. Fe, Cu vs. Al, Mn vs. Fe) indicate that the respective elements are hosted in different minerals of which one is (or both are) unevenly distributed, while positive correlations ( $\mathrm{Fe}$ vs. $\mathrm{Cu}, \mathrm{Mn}$ vs. $\mathrm{Ca}, \mathrm{Mn}$ vs. $\mathrm{Mg}, \mathrm{P}$ vs. $\mathrm{Fe}, \mathrm{Zn}$ vs. $\mathrm{Cu}$ ) suggest that these elements occur at least partly in the same mineral or mineral association.

The correlations can be used to address two main questions on the Musina mine tailings: first, the mode of occurrence of $\mathrm{Cu}$, and second, those of $\mathrm{Fe}$ and $\mathrm{Ca}$, related to the potential for acid mine drainage generation. A correlation of Fe with $\mathrm{Cu}(r=0.358$, but the slope is 1.9) indicates that $\mathrm{Cu}$ chiefly occurred as chalcopyrite (atomic $\mathrm{Cu}$ / Fe ratio $\approx 1$ ) associated with pyrite during deposition of the tailings. This correlation is superimposed on a large amount of $\mathrm{Fe}$ in excess to this association that is uncorrelated with $\mathrm{Cu}$. Further, Fe and $\mathrm{Mg}$ are negatively correlated, which means that this excess Fe was not primarily hosted in minerals like chlorite or smectite (which would also be leached by aqua regia). The negative correlation of $\mathrm{Mn}$ with Fe (Fig. 2) further indicates that neither Fe, nor $\mathrm{Mn}$ exists primarily as $\mathrm{Fe}-\mathrm{Mn}$ oxyhydroxide coatings on grains, which form under oxidising weathering. Taken together, this points to Fe being present mainly as pyrite.

The acid-generating potential of the tailings is therefore a concern. No $S$ analyses were carried out in this study. For acid-base accounting (ABA) using the traditional Sobek method, 4.8 $\mathrm{N}$ hydrochloric acid and $2 \mathrm{~N}$ nitric acid are used sequentially to leach the sulphate and sulphide sulphur, respectively, and carbonate content is analysed by titration [15]. With an aqua regia leach as carried out in this study, analysing for $\mathrm{S}$ is uninformative, as it does not discriminate sulphide and sulphate-hosted S. However, the metal content correlations yield helpful information. First, the positive correlation of $\mathrm{Mn}$ with Ca coupled with the absence of any correlation between $\mathrm{Mg}$ and $\mathrm{Ca}$ indicates that extractable Ca mainly occurs as calcite. This is because $\mathrm{Mn}$ is highly compatible in calcite [14]. The additional correlation of $\mathrm{Mn}$ with $\mathrm{Mg}$, which indicates its presence in clay minerals or chlorite, does not detract from this conclusion. Thus, the tailings contain some neutralisation potential. However, the average molar ratio of $\mathrm{Ca}: \mathrm{Fe}$ is 0.3 and of $(\mathrm{Ca}+\mathrm{Mg})$ : $\mathrm{Fe}$ is 1.06 , and as $2 \mathrm{~mol}$ of divalent cations are required to neutralise the acid produced from $1 \mathrm{~mol}$ of pyrite [15], the Musina mine tailings would be expected to produce some acid drainage and it is puzzling that the measured $\mathrm{pH}$ values are neutral to slightly basic. A possible explanation is that pyrite is already partly oxidised in situ. An indication for this is given by the presence of gypsum and also the positive correlation of $\mathrm{P}$ with $\mathrm{Fe}$ (the only positive correlation found for $P$ ), which can only be explained by adsorption of phosphate from solution. As the surface of a pyrite grain is oxidised, an iron oxide hydroxide layer is formed. Phosphate ions are irreversibly adsorbed onto this, and even minimal amounts of adsorbed phosphate have been found to prevent further oxidation of the pyrite [16]. From a metallurgical perspective, this is interesting: the high levels of Fe (up to 6\%), if wholly present as sulphides, could create problems in recovering $\mathrm{Cu}$, as iron sulphides normally float with $\mathrm{Cu}$, making $\mathrm{Cu}$ and Fe separation difficult and consequently rendering liberation an 

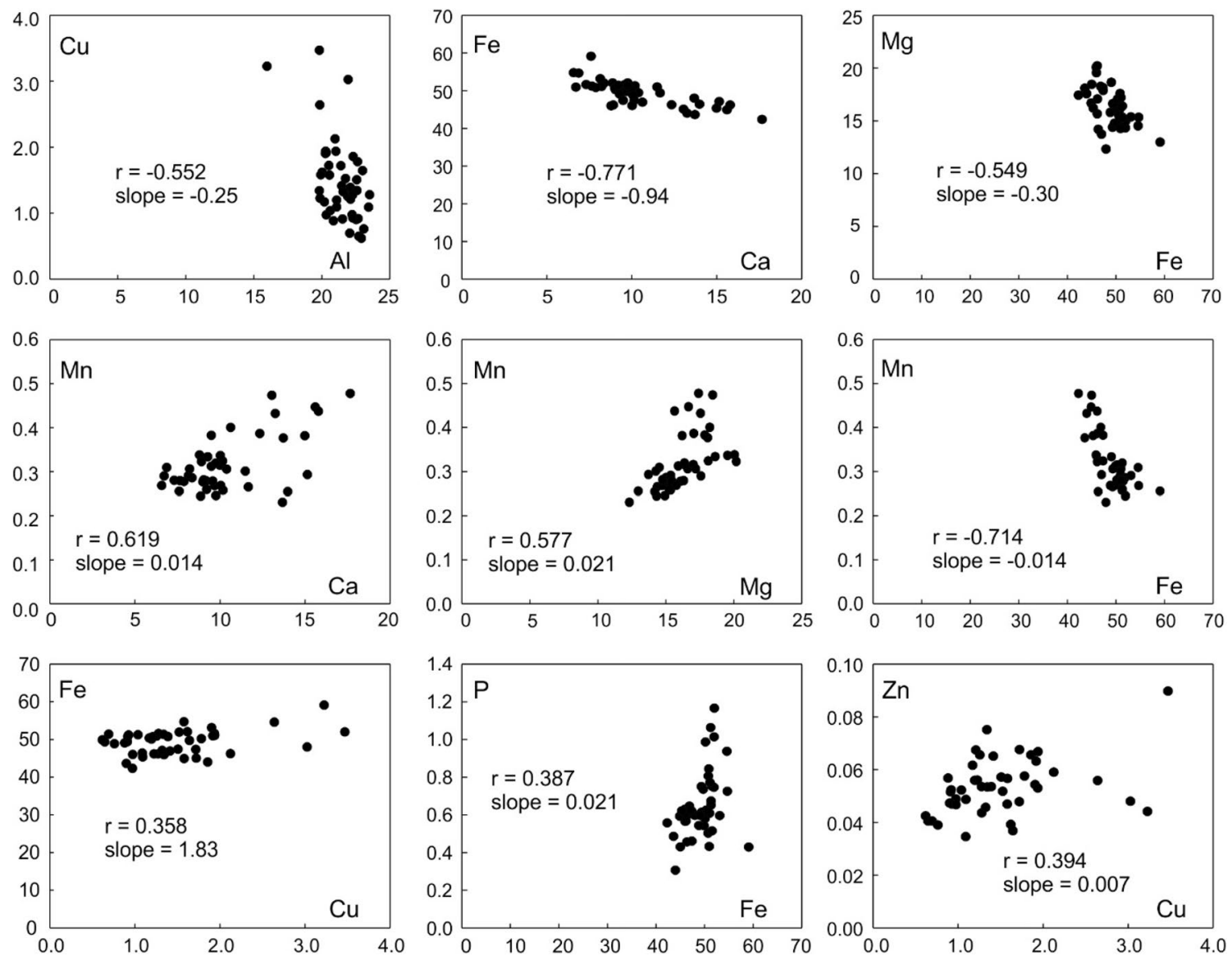

Fig. 2 Two-element plots showing correlations between element abundances as percentages (by mass) of the sum of concentrations of analysed elements as listed in Table S3

issue [1]. If Fe sulphides are coated with hydroxides and phosphate, this problem would be less severe.

\subsection{Distribution of copper in the auger holes}

While drilling, it was observed that there were a general homogeneity and lack of distinct layering in the tailings, and this is confirmed by the lack of systematic variation in $\mathrm{Cu}$ concentrations with depth in all boreholes, shown in Fig. 3.

In all borehole profiles, there is a generally sufficiently high concentration of $\mathrm{Cu}$ (mean $940 \mu \mathrm{g} / \mathrm{g}$ ) to be extractable economically. Copper is what the previous operator was attempting to recover, and recovery was clearly poor in some instances. This can be observed at a depth of 3-4 $\mathrm{m}$ in boreholes KSM04, KSM05 and KSM08 (Fig. 3).

All profiles show different patterns of localised enrichment of $\mathrm{Cu}$ with depth. It is therefore highly unlikely that there is a single leaching mechanism operating whereby the metal would be transported downwards via seepage. Boreholes KSM04 and KSM05 were drilled in a waterlogged area of the tailings dump, where a consistent distribution with depth would be most likely to result if leaching was a major factor controlling concentration. However, their distribution patterns are irregular and not mutually similar. Thus, it is more likely that variations in Cu concentration are simply caused by fluctuations in the concentration of the ore mineral, or minerals, in suspension as the tailings dump was deposited over time. This is in accord with the above conclusion that $\mathrm{Cu}$ was deposited mainly as chalcopyrite.

\subsection{Harmful elements assessment summary}

The Musina mine tailings have no detectable concentrations of $\mathrm{Pb}, \mathrm{Cd}$ or As (Supplementary Table S1). This finding, together with the neutral to weakly basic $\mathrm{pH}$ values, indicates a low environmental and health risk from these elements. The high concentrations of $\mathrm{Cu}$ are, however, a concern. While $\mathrm{Cu}$ is unlikely to present an important groundwater or surface (river) water contamination, its dispersion in dust in the dry season could pose a health risk to the large population living in the immediate vicinity. Ingestion of can lead to its damaging accumulation 


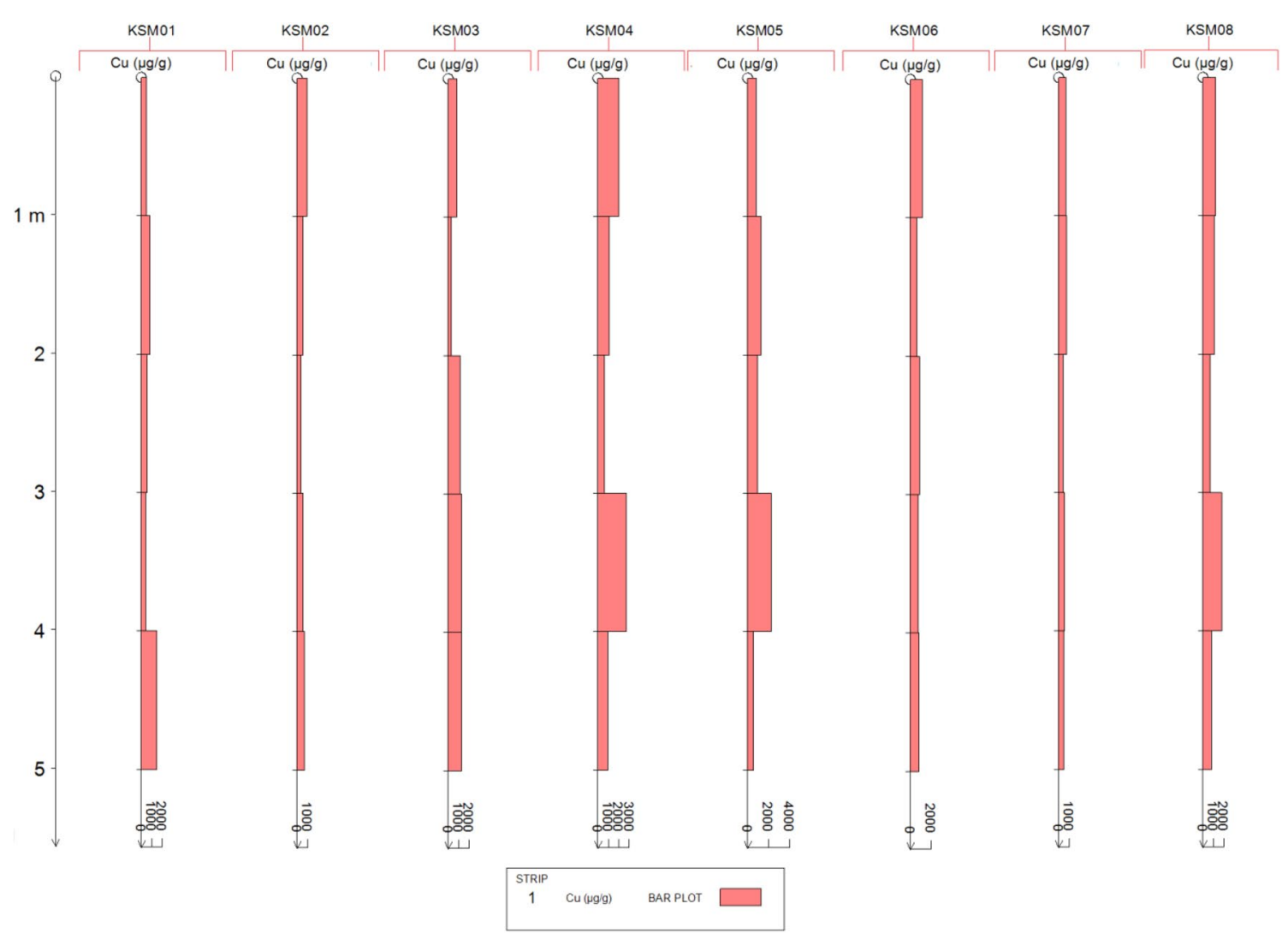

Fig. 3 Strip log showing Cu metal concentration and distribution in boreholes

in liver, brain, kidney and cornea. A retreatment of the tailings dump to extract copper would have the added advantage of mitigating this risk.

\subsection{Modelling and resource estimation}

In order to evaluate the economic feasibility of reclaiming the Musina tailings dump, the $\mathrm{Cu}$ concentrations of the borehole samples were incorporated in a block model of the dump. This involved constructing a 3D model as described below.

\subsection{Triangulation and block model design}

Solid triangulations or wireframes were generated from the interpretation of drill hole sections. Line sections were digitised from each drill hole, snapping to the collar points for top surfaces and end-of-hole points for basement surfaces. The ideal method of modelling a tailings dump is through 3D laser scanning to output point cloud data points for high resolution.

\subsection{Block model design}

A block model was created for the entire tailings dump area and included the upper and bottom surfaces as constraints. The block model definition files were generated with the following parameters (Table 2):

Air blocks outside dump domains were deleted to optimise block model size and to ensure that no air blocks outside the dump wireframe were estimated. The block model was validated through visual inspections and creating diagonal sections across dump domains. For visualisation purposes, the tailings dump has been exaggerated 10 times in the $Z$ dimension.

Block model validation shows that no air blocks exist outside dump domains. Multiple sections were created across the dump-modelled surfaces to identify any irregularities in the block model design. The block model of the Musina mine tailings dump (Supplementary Figs. S4-S7) is valid and accurate for the next stage of resource estimation. 
Table 2 Limits of the block model of the Musina Copper Mine tailings dump

\begin{tabular}{|c|c|c|c|c|c|}
\hline \multicolumn{6}{|l|}{ Model extent } \\
\hline Origin $\mathrm{X}$ & & Origin $Y$ & & Origin Z & \\
\hline Coordinates & $195,400.0$ & Coordinates & $7,527,000.0$ & Coordinates & 514.0 \\
\hline Extent on $\mathrm{X}$ & 1700.0 & Extent on $\mathrm{Y}$ & 1900.0 & Extent on Z & 50.0 \\
\hline Block sizes & Block X size (m) & & Block Y size (m) & & Block Z size $(\mathrm{m})$ \\
\hline Parent cell & 10.0 & & 10.0 & & 0.5 \\
\hline
\end{tabular}

Note The extent on $\mathrm{X}, \mathrm{Y}, \mathrm{Z}$ is the distance in metres $(\mathrm{m})$ added on original coordinates to cover the extent of the model. Starting coordinate points are Universal Transverse Mercator (UTM) 36 coordinates
Table 3 Musina Copper Mine dump: Cu general statistics in $\mu \mathrm{g} / \mathrm{g}$ (g/tonne)

\begin{tabular}{ll}
\hline Cu_Musina Mine.cmp: Cu ( $\mu \mathrm{g} / \mathrm{g}$ [g/tonne]) & \\
\hline Number of samples & 45 \\
Minimum & 326.45 \\
Maximum & 2741.42 \\
Range & 2414.97 \\
Average (mean) & 954.20 \\
Standard deviation & 493.26 \\
Variance & 243306.84 \\
Geometric mean & 852.76 \\
Geometric variance & 1.25 \\
Harmonic mean & 769.98 \\
Skewness & 1.60 \\
Fisher kurtosis & 2.85 \\
Nat. log mean & 6.75 \\
Nat. log variance & 0.22 \\
Coef. of variance & 0.52 \\
Sichel t & 951.98 \\
Q1 & 595.19 \\
Median & 819.68 \\
Q3 & 1177.44 \\
\hline
\end{tabular}

\subsection{Statistics (composite data)}

Further statistical analysis was conducted for the tailings dump-analysing grade variables $(\mathrm{Cu})$ in the databases because raw drilling databases cannot be used for grade estimation without statistics. As a result, a compositing method was used to break down assays into equal sampling lengths. As boreholes were sampled at 1-m intervals, a $1 \mathrm{~m}$ length compositing method was chosen to ensure that sample support remained constant [9]. Computational compositing is a method of breaking down a sample set according to how it was sampled in the field and in the laboratory during sample analysis [37]. The 1-m compositing method chosen resulted in a composite database with downhole mid-sample points that were used in grade estimation. Basic statistics were investigated for the composited databases (Table 3). All these samples were used in variography modelling. Table 3 presents general statistics analysed for all grade samples.

The histogram presented in Fig. 4 illustrates sample counts compared to sample grades. The purpose of presenting this histogram is to identify outliers (anomalous samples) that can be removed from the sample database
Fig. 4 Cu histogram for the Musina mine tailings dump

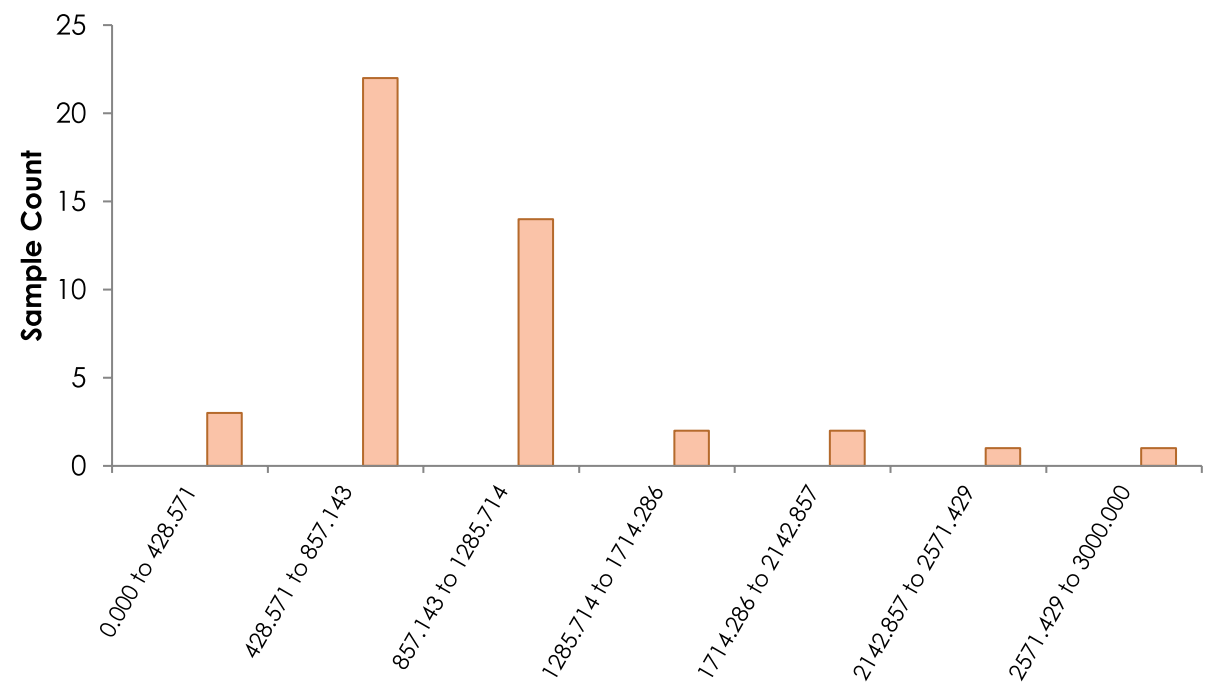


or suppressed prior to variogram modelling. Outliers may cause confusion when correlating variogram models. Outliers are generally identified and suppressed for the purpose of variogram modelling, but later returned for grade estimation. This type of comparison enabled to determine whether the composite data require any transformation in preparation for variogram modelling. In some cases, the data can present positively or negatively skewed distributions. This may then require transformation; for example, Gaussian transformation, prior to variogram modelling and grade estimation.

It is important to note that the distribution of elements in the tailings is essentially attributed to how material has been dumped. This is not a natural deposit-geologically formed and in situ; instead, it is synthetic. Because of this, it is difficult to draw robust conclusions in this case. The observation (Sect. 4.3) that no significant enrichment or depletion in Cu with depth has been noted (nor for the other elements analysed in this study) indicates that the effects of the dumping season and fluctuating mining operations dominate.

\subsection{Resource block model validation}

Various methods were used to validate the estimate against the composite data, including visual validation and drift analysis, also known as swath plots (Supplementary Figs. S8-S10). Visual validation was performed by viewing cross sections and comparisons of the grade in the block model to the sample database. The correlation between the sample grades and the block model was good.

\subsection{Mineral tonnage estimations and resource reporting}

No relative density measurements have been conducted in the University of Johannesburg laboratory for this project. The tonnages calculated are based on densities obtained from previous studies. From the density of quartz ( 2.32 ton $/ \mathrm{m}^{3}$ ) and the minor component amphibole (c. 3.1), loose sand (1.44) and considering that the tailings are compacted, a value of $1.7 \mathrm{ton} / \mathrm{m}^{3}$ was used for the Musina mine.

Sufficient high-quality data were collected, increasing the confidence in the tailings dumps determination. The total tonnage of tailings material was used to deduce the total amount of elements. The total area of the tailings dumps at the Musina mine is 95 hectares (ha) $(950,000$ $\mathrm{m}^{2}$ ) as given by the model and the volume calculated is $4,750,000 \mathrm{~m}^{3}$. The average density is $1.7 \mathrm{ton} / \mathrm{m}^{3}$. No geological losses were included in the mineral resource estimation as there should not be any structure (dyke or sill) present in the dump that will cause losses and a 100\% reclamation of the dump is assumed. These values were calculated and tabulated in Microsoft Excel (Table 4).

The cut-off grade is the lowest grade material constituting all or part of an ore body that can be profitably treated. It is anticipated that the Musina dumps would be reclaimed by hydraulic mining, which is normally used for this type of deposit. This dump reclamation method makes the mining of selective areas or layers difficult, making a cut-off grade possibly irrelevant. A cut-off grade was, however, applied in the resource estimation as it is assumed that the tailings dump might be reclaimed using several options, depending upon the technology available at the time.

In order to check for potential biases in the block model grade estimate, the inverse distance block grades were compared to the OK estimation at a zero-cut-off grade. Ordinary kriging estimations provide more robust estimates of the mean grade of tailings because the sample data of drill holes are declustered. Figure 5 compares the exploitable grades (in ppm, i.e. g/tonne) and tonnages as a function of the cut-off grade, two grade models at a zero cut-off grade for two mineral resource categories.

\section{Conclusions}

Conclusions from this study relate to (a) economic potential through exploitability, (b) environmental and health risks and (c) potential for other purposes.

The results presented in this paper indicate the lack of full copper recovery by the operator, leading to a significant amount of $\mathrm{Cu}$ (up to 8555 tonnes) still in the tailings, and can be concluded that the processing plants were not efficient during earlier days. A correlation between Fe and Cu suggests that the $C u$ was deposited in the tailings as an association of chalcopyrite and pyrite.

A geometallurgical study would help assess the economic feasibility of extracting $\mathrm{Cu}$, with a view to reworking these tailings.

Table 4 Mineral resource estimation of the Musina mine tailings dumps

\begin{tabular}{llllllllll}
\hline Metals & Mean $(\mu \mathrm{g} / \mathrm{g})$ & Grade $(\%)$ & Dump tonnage & Metal tonnage & Density & Ha & Area $\mathrm{m}^{2}$ & Average dump height $(\mathrm{m})$ & Volume $\left(\right.$ dump) $\mathrm{m}^{3}$ \\
\hline $\mathrm{Cu}$ & 943.84 & 0.09 & $80,75,000$ & 8555.43 & 1.7 & 95 & $9,50,000$ & 5 & $47,50,000$ \\
\hline
\end{tabular}

${ }^{\mathrm{a}} \mathrm{ppm}(\mu \mathrm{g} / \mathrm{g}) / 10000=\%$ 

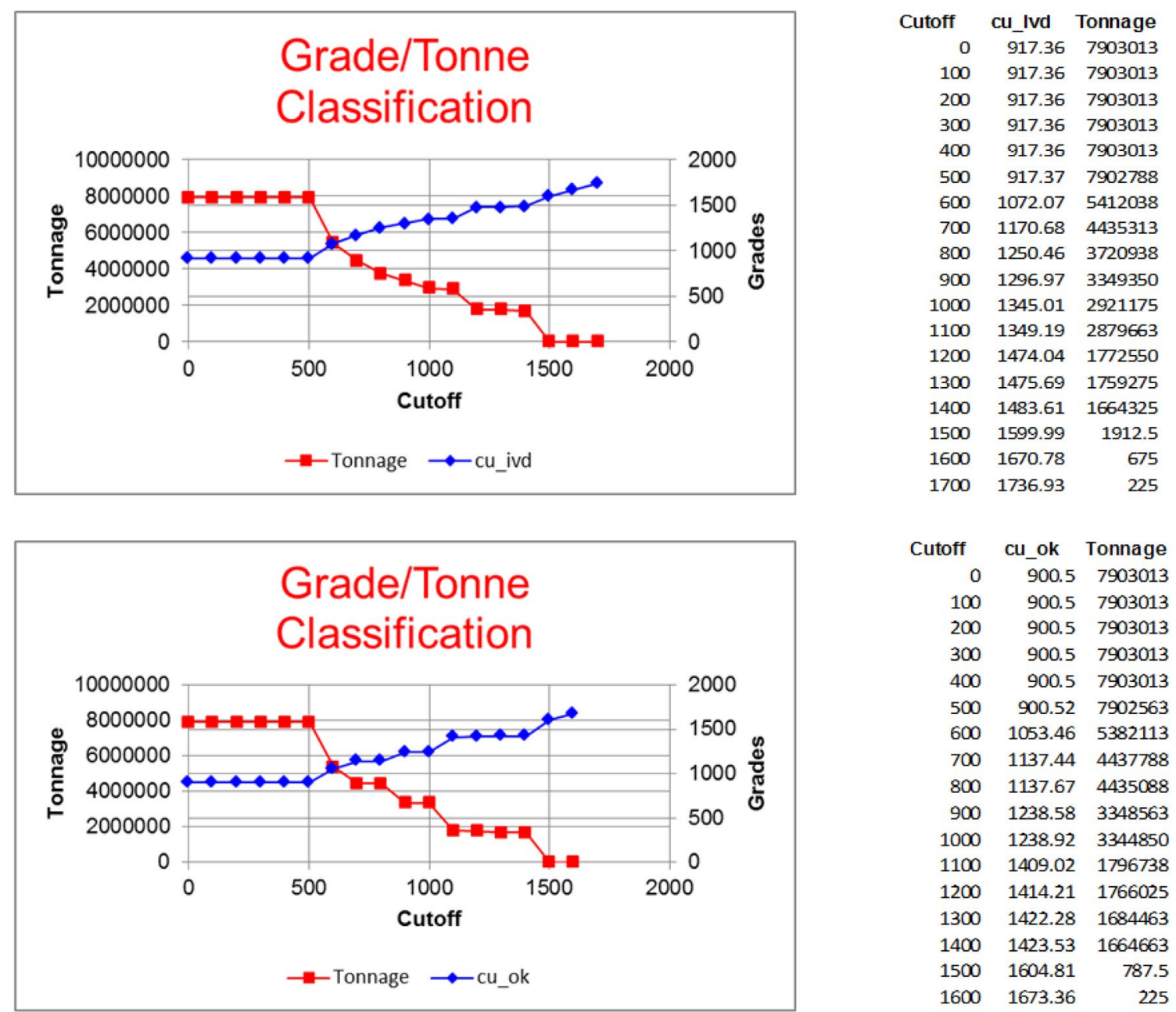

Fig. 5 Musina mine tailings dump grade/tonne report for Cu comparing OK (cu_ok) and IVD (cu_ivd) estimation

Tailings, specifically those that are in close proximity to nearby communities, should be removed or remained in a wet process (unearthing them would release dust laden with possibly toxic elements). While up to $6 \%$ Fe may be present in the tailings as pyrite and insufficient neutralisation potential is present, the samples present neutral to slightly basic $\mathrm{pH}$ and we suggest that the formation of AMD is prevented by Fe oxyhydroxide coatings with adsorbed phosphate. As long as $\mathrm{pH}$ remains non-acidic, the metal levels in tailings solution and plants would remain below toxic levels. It is important that these tailings are rehabilitated in future, to ensure the sterilised land can be used for other purposes. Mining the tailings for copper could offer a self-funding option that has the potential to complete proper rehabilitation.

The main risk is associated with the possible inhalation or ingestion of dust, and any remediation of the tailings dumps and rock dumps should include stabilising the surface (e.g. by using vegetation). As it stands, short-term solutions include rehabilitating tailings and rock dumps with vegetation cover in order to prevent loose soil from being blown or washed away by wind and water, and relocating communities living in affected areas.

Acknowledgements Research support from the NRF to JDK (grants 81022 and 115260) is gratefully acknowledged.

Author's contributions Material in this article is from the first author $\mathrm{PhD}$ thesis and the co-author contributed equally to this article as a supervisor.

Funding The analytical work was funded jointly by the Geological Society of South Africa Research Education and Investment Fund (GSSA REI) and the DST-NRF Centre of Excellence for Integrated Mineral and Energy Resource Analysis (CIMERA).

\section{Compliance with ethical standards}

Conflict of interest The authors declare that no competing interests exist. 
Availability of data and materials We confirm data were created during the research and they are available.

Open Access This article is licensed under a Creative Commons Attribution 4.0 International License, which permits use, sharing, adaptation, distribution and reproduction in any medium or format, as long as you give appropriate credit to the original author(s) and the source, provide a link to the Creative Commons licence, and indicate if changes were made. The images or other third party material in this article are included in the article's Creative Commons licence, unless indicated otherwise in a credit line to the material. If material is not included in the article's Creative Commons licence and your intended use is not permitted by statutory regulation or exceeds the permitted use, you will need to obtain permission directly from the copyright holder. To view a copy of this licence, visit http://creativecommons .org/licenses/by/4.0/.

\section{References}

1. Agorhom EA, Lem JP, Skinner W, Zanin M (2015) Challenges and opportunities in the recovery/rejection of trace elements in copper flotation-a review. Miner Eng 78:45-57

2. Ahmadi A, Khezri M, Abdollahzadeh AA, Askari M (2015) Bioleaching of copper, nickel and cobalt from the low grade sulfidic tailing of Golgohar Iron Mine. Iran Hydrometallurgy 154:1-8

3. Bahnemann KP (1986) A review of the geology of the Musina copper deposits Northern Transvaal. In C.R. Anhaeusser, S. Maske (eds) Mineral deposits of Southern Africa, 5th edn. The Geological Society of South Africa: Johannesburg, 2:16-73

4. Brime C (1985) The accuracy of X-ray diffraction method for determining mineral mixtures. Miner Mag 49:531-538

5. Bryan CG, Hallberg KB, Johnson DB (2006) Mobilisation of metals in mineral tailings at the abandoned São Domingos copper mine (Portugal) by indigenous acidophilic bacteria. Hydrometallurgy 83:184-194

6. Carmen F, Barry M, Grail D, Barrie J (2016) New approaches for extracting and recovering metals from mine tailings. Miner Eng 15(106):71-78. https://doi.org/10.1016/j.mineng.2016.10.008

7. Chung $\mathrm{Cl}$ (1974) Unsolved problems in polymer processing. 2(3):VI. https://doi.org/10.1111/j.2164-0947.1974.tb01582.x

8. Clare AP, Cohen DR (2001) A comparison of unsupervised neural networks and k-means clustering in the analysis of multielement stream sediment data. Geochem Exploration Environ Anal 1:119-164

9. Coombes J (1997) Handy Hints for Variography. In: Proceedings 1997 AusIMM annual conference-National conference on iron making resources and reserves estimation. The Australian Institute of Mining and Metallurgy, Melbourne, pp 127-130

10. Cox KG, Johnson RL, Monkman LJ, Vail JR, Wood D (1965) The geology of the Nuanetsi igneous province. Philos Trans Roy Soc A 257:71-218

11. Daniel A, Downing BW (2011) Investigating the reprocessing of Carolin mine tailings. Tailings and Mine Waste 2011, Vancouver, Canada, pp 65

12. Department of Mineral Resources (DMR) (2009) The national strategy for the management of derelict and ownerless mines in South Africa, 4.

13. Dreisinger DB (2016) Case study flowsheets: copper-gold concentrate treatment, gold ore processing, Chapter 44, 2nd edn. Project Development and Operations, pp 803-820
14. Dromgoole EL, Walter LM (1990) Iron and manganese incorporation into calcite: effects of growth kinetics, temperature and solution chemistry. Chem Geol 81:311-336

15. Downing BW (2014) Acid-base accounting test procedures. In: Jacobs JA, Lehr JH, Testa SM (eds) Acid mine drainage, rock drainage, and acid sulfate soils: causes, assessment, prediction, prevention, and remediation. Wiley, New York, pp 217-227

16. Elsetinow AR, Schoonen MAA, Strongin DR (2001) Aqueous geochemical and surface science investigation of the effect of phosphate on pyrite oxidation. Environ Sci Technol 35:2255-2257

17. Grobbelaar C, Handley MF (2000) Mine closure: transformation of defunct liabilities into profitable asset. HIEP (SA) Pty Ltd and University of Pretoria, pp 1-9

18. Holzer L, Barton JM Jr, Paya BK, Kramers JD (1999) Tectonothermal history in the western part of the Limpopo Belt: test of tectonic models and new perspectives. J Afr Earth Sci 28:383-402

19. Holzer L, Frei R, Barton JM Jr, Kramers JD (1998) Unraveling the record of successive high grade events in the Central Zone of the Limpopo Belt using $\mathrm{Pb}$ single phase dating of metamorphic minerals. Precambrian Res 87:87-115

20. ISO 10390 (1994) Soil quality-determination of pH. International Organization for Standardization. Geneva, Switzerland 5. www.iso.ch. Accessed 12 May 2020.

21. ISO 11464 (1994) Soil quality-pre-treatment of samples for physico-chemical analysis. International Organization for Standardization. Geneva, Switzerland. 9. www.iso.ch . Accessed 12 May 2020.

22. ISO 11466 (1995) Soil quality-extraction of trace elements soluble in aqua regia. International Organization for Standardization. Geneva, Switzerland. 6. www.iso.ch. Accessed 12 May 2020.

23. Jambor JL (2003) Mine-waste mineralogy and mineralogical perspectives of acid-base accounting. In: Jambor JL, Blowes DW, Ritchie AIM (eds) Environmental aspects of mine wastes, Mineralogical Association of Canada, vol 31, pp 117-145, Ottawa, Canada.

24. Kamber BS, Kramers JD, Napier R, Cliff RA, Rollinson HR (1995) The Triangle Shear Zone, Zimbabwe, revisited: new data document an important event at $2.0 \mathrm{Ga}$ in the Limpopo Belt. Precambr Res 70:191-213

25. Kramers JD, Mouri H (2011) The geochronology of the Limpopo Belt: A controversy solved. In: Van Reenen DD, Kramers JD, McCourt S and Perchuk LL (eds) Origin and evolution of Precambrian high-grade gneiss terrains, with special emphasis on the Limpopo complex of Southern Africa. Geological Society of America Memoirs, vol 207, pp 311-314

26. Limpitlaw D (2004) Mine closure as a framework sustainable development.University of the Witwatersrand, 8-10 March 2004, 8

27. Mackasey WO (2000) Abandoned mines in Canada. Report prepared for Mining Watch Canada

28. Mason CM (1973) The geology of the country around Evangelina and Pontdrift (2228 BD and 2229 A). Unpublished report, Geological Society of South Africa, $p 70$

29. Palmer JP (2006) Reclamation and decontamination of metalliferous mine tailings, mine water and the environment. International Water Association, pp 223-230

30. Rajaram V, Robinson B (2005) Mine land reclamation. In: Rajaram V, Dutta S, Parameswaran K (eds) Sustainable mining practices: a global perspective. Balkema Publishers, Leiden, pp 179-191

31. Rerani V (2013) Geotechnical characteristics of mine tailings at Musina Copper Mine, Limpopo. MSc dissertation (unpublished), University of Venda, Thohoyandou, Limpopo 
32. Richard M, Kahinda JM (2011) Socio-economic profile of Musina local municipality and the A63E and A71 L sub-basins, Limpopo River Basins, Limpopo River Basin, South Africa. Technical Report (PDF Available), September 2011. Report number: CSIR/NRE/ WR/ER/2011/0128/A

33. Robert MK, Du Toit MC (1981) The importance of being alkaline-deformed late Achaean lamprophyric dykes, Central Zone, in Limpopo Belt Transactions. Trans Geol Soc South Africa 88:195-206

34. Schaller EA, Compston W, Armstrong RA, Williams IS (1999) Characteristics and preliminary $\mathrm{U}-\mathrm{Pb}$ ages of zircon from Limpopo Belt lithologies, extended abstracts. Rand Afrikaans University, Johannesburg, Limpopo workshop, pp 95-99

35. Scharer JM, Pettit CM, Kirkaldy JL, Bolduc L, Halbert BE and Chambers DB (2000) Leaching of metals from sulphide mines waste at neutral pH. In: ICARD 2000 Proceedings from the Firth international conference on acid mine drainage, Society for Mining, Metallurgy, land exploration, Inc, 1:191-201

36. Swart E (2003) The South African legislative framework for mine closure, Proceedings of the colloquium on mine closure for sustainable development, South African Institute of mining and metallurgy, Johannesburg, SA. ISSN 0038-22 3Y300, pp 489-492
37. Thomas G, Coombes J, Richards WL (1998) Practical conditional simulation for geologists and mining engineers. In: Proceedings, Third Regional Symposium, Western Australia, pp 19-26

38. TriAusMin (2020) Woodlawn retreatment project. Retrieved, 2020, from https://www.trioriginminerals.com.au/projects. asp?id=4

39. Williams L (2009) Amerigo's Copper/Moly Output from El Teniente Tailings Reaching New Records. Retrieved, 2011, from https ://www.mineweb.com/mineweb/view/mineweb/en/page6 6 ? oid $=93691 \&$ sn=Detail

40. Wilson MGC (1998) Copper: the mineral resources of South Africa. In: Wilson MGC, Anhaeunsser CR (eds) Handbook 16, 6th edn, p 209

Publisher's Note Springer Nature remains neutral with regard to jurisdictional claims in published maps and institutional affiliations. 